\title{
REDUCTION IN AQUEOUS HUMOUR FORMATION AS CAUSED BY IODATE, SPIROLACTONE, AND POLYPHLORETIN PHOSPHATE*
}

\author{
BY \\ D. F. COLE \\ Ophthalmological Research Unit, (Medical Research Council), Institute of Ophthalmology, University \\ of London
}

SINCE the formation of the aqueous humour depends largely upon active transport across the blood-aqueous barrier (in particular the ciliary epithelium), the rate of formation will be influenced by substances which act upon the barrier by modifying its properties or behaviour. In the present paper results are presented which deal with the actions of three different types of substance, all of which diminish the rate of formation of the aqueous.

Evidence for a mechanism transporting sodium ions actively from the plasma to the aqueous has been discussed elsewhere (Cole, 1960b, 1961a), and it was thought that such a system might be subject to inhibition by an aldosterone antagonist, spirolactone, which has been shown to reduce sodium reabsorption in the renal tubules (Cella and Kagawa, 1957; Kagawa, Cella, and van Arman, 1957; Liddle, 1957, 1958; Vander, Wilde, and Malvin, 1960). Noell $(1953,1954)$ has shown that chronic administration of iodate, which has long been known to cause pathological changes of the pigment epithelium (Vito, 1935; Kalt, 1937; Sorsby, 1941), abolishes the steady retinal potential as a result of this selective damage. It appeared possible that this action on the pigmented cells might not be confined to the retina but might also extend anteriorly into the pigment-cell layer of the ciliary body and thereby interfere with the normal production of the aqueous humour. The third substance studied was polyphloretin phosphate, which has already been shown to prevent experimental ocular hypertension caused by increased permeability of the blood-aqueous barrier (Cole, 1961b). The possibility that ultrafiltration across the normal barrier contributes to the influx measured in experiments of the present type has already been raised (Cole, 1960b), and it was thought that, in contrast to the other two inhibiting agents, spirolactone and iodate, polyphloretin phosphate would tend to reduce this ultrafiltration component without inhibiting the active transport processes. ' 


\section{Experiments}

Animals.-Adult male albino rabbits (New Zealand White strain) were used in all experiments. The animals weighed between 2.5 and $3 \mathrm{~kg}$., and were fed on Diet 18 ("Blue Cross" Animal Foodstuffs, Associated London Flour Millers Ltd.) with free access to water.

All the experiments, with the exception of those concerned with the long-term effects of iodate administration, were conducted under urethane anaesthesia, the drug being given intravenously as a 25 per cent. (w/v) solution in 0.9 per cent. saline, $1.75 \mathrm{~g}$. urethane per $\mathrm{kg}$. body weight.

\section{Iodate}

(a) Long-term Experiments.-After a control period of 3 or 4 days, during which the intra-ocular pressure in both eyes was measured with the Schiötz tonometer using a $5 \cdot 5-\mathrm{g}$. weight, the rabbits were given from 3 to $5 \mathrm{ml} .2$ per cent. (w/v) solution of sodium iodate intravenously. Intra-ocular pressure measurements were continued daily for a further 12 days, at the end of which time the animals were anaesthetized with urethane and the influx rates of water, sodium, and chloride in one eye estimated by the collection of aqueous under a constant pressure of 18 $\mathrm{mm}$. $\mathrm{Hg}$, using a needle inserted through the cornea into the anterior chamber after the outflow channels had been obstructed with silicone fluid MS/200/20 (Hopkin and Williams Ltd., London, England) (Cole, 1960a, b). When the inflow measurements were completed the animal was killed and the Schiötz tonometer calibrated with respect to each eye by applying known pressures from a reservoir through a needle inserted through the cornea. The stopcock between the eye and the reservoir was closed while the tonometer readings were obtained. A control series of rabbits was used in which 0.9 per cent. saline was injected intravenously instead of 2 per cent. sodium iodate.

Some of the iodate-treated animals were reserved for histological study; these were anaesthetized with Nembutal 14 days after the iodate had been given and the eyes were fixed intravitally with Zenker's solution.

(b) Acute Experiments.-Rabbits were anaesthetized with urethane and a cannula was inserted in the left lingual artery (Cole, 1959) through which saline or sodium iodate solution could be infused. The influx rates for water, sodium, and chloride were estimated in the left eye as in the long-term experiments. During the first $20 \mathrm{~min}$. of the experiment, isotonic saline was infused into the lingual artery (control period) and this was followed by infusion of sodium iodate at $0.01 \mathrm{mM} /$ min. for a further $30 \mathrm{~min}$. The animal was then killed.

In some cases the blood-aqueous potential difference (P.D.) was recorded, using one electrode in the ear vein and a second in the posterior chamber (Cole, 1961a). The input impedance of the voltage measuring device was $10^{13} \mathrm{ohms}$.

Spirolactone.-The substance used in these experiments was SC-8109, aldactone, one of the steroid-17-spirolactones described by Cella and Kagawa (1957). Preliminary trials showed that either polyethylene glycol 400 or propylene glycol would be a suitable medium for administering the substance which is not very soluble in water. Intravenous administration in polyethylene glycol at a rate of $20 \mathrm{mg}$./ kg. body weight was used in the earlier experiments, but in the later ones the drug 
was given via the left common carotid. The carotid artery was chosen so that a cannula of larger diameter might be employed in order to overcome the difficulties arising from the viscosity of polyethylene glycol or propylene glycol.

The device used for injection consisted of two polythene cannulae (A, B, Fig. 1) connected to a Perspex T-piece by short lengths of "Portex" tubing (Portland Plastics Ltd., Hythe, Kent). The tubes, A and B, and the T-piece, together with its side-arm, C, were filled before the experiment with a solution of heparin (20 I.U. per ml.), the side-arm being connected to a motor-driven hypodermic syringe containing polethylene glycol or propylene glycol by a further length of "Portex" tubing.

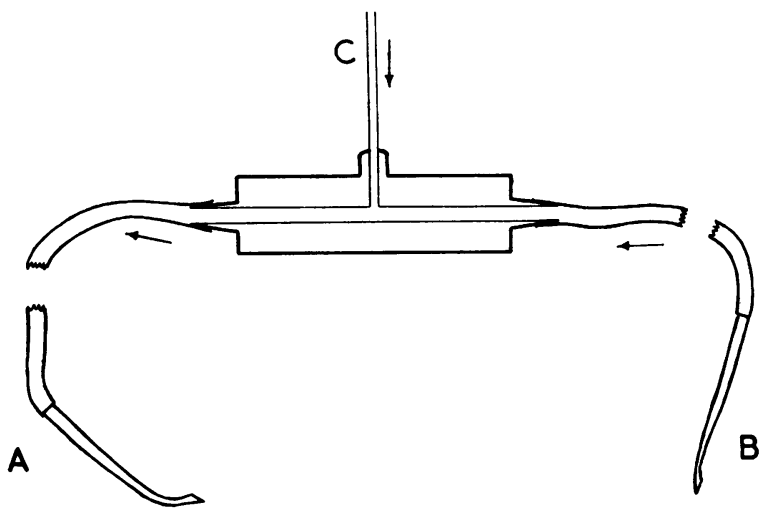

Fig. 1.-Device used for intra-carotid infusions.

$A$ and $B$ polythene cannulae for insertion into the artery.

The side-arm, C, of the perspex T-piece conveys the solution to be

infused and is connected to a motor-driven hypodermic syringe.

Arrows indicate direction of flow of blood and injected fluid.

After the animal had been anaesthetized with urethane in the normal way, the left common carotid was exposed and cleaned for about an inch and a half of its length, and two loose ligatures were placed round the artery at each end. Two more loose ligatures were placed round the artery, beyond the first pair and passing through the substance of the scalene muscles. After the length of artery had been isolated with bulldog clips at each end, the cannulae were inserted and tied in place, starting with the proximal one. The body of the proximal cannula was then anchored by means of the distal scalenus ligature and the distal cannula by the proximal scalenus ligature. This procedure ensured that both cannulae lay parallel to the line of the artery. The bulldog clips were removed and flow through the T-piece allowed to commence.

The carotid cannulae having been inserted the influx rates for the left eye were measured as described above after a control period of $20 \mathrm{~min}$., and in some animals the blood-aqueous P.D. was recorded.

Polyphloretin Phosphate (PPP).-This is a substance of high molecular weight (MW =15,000; Diczfalusy, Ferno, Fex, Hogberg, Linderot, and Rosenberg, 1953) which has been shown to diminish the permeability of damaged capillaries and of serous membranes (Fries, 1956, 1960). $0.05 \mathrm{ml} . / \mathrm{min} .10$ per cent. solution of PPP 
in isotonic saline was infused via the left common carotid artery using the operative procedure described for the spirolactone experiments. The influx rates for the left eye were measured after a control period as above and in some animals recordings of the blood-aqueous P.D. were made.

Chemical Estimations.-Plasma protein, sodium, and potassium and aqueous sodium and potassium were estimated by methods described previously (Cole, 1960b). Chloride in plasma and aqueous was determined, using a micro-modification of the method of Bertolacini and Barney (1958).

\section{Results}

The influx rates for each 5-min. interval were calculated from the outflow and solute concentration of the fluid collected from the anterior chamber (Cole, 1960b). The results are shown in Fig. 2, and in Figs 3 and 4 (overleaf).

Values for the mean influx rates before and after infusing the drug were also calculated (Table I, opposite), and in this case the control mean was estimated from the values lying between 20 and $5 \mathrm{~min}$. before starting the drug infusion (i.e. from -20 to $-5 \mathrm{~min}$. in Figs 2 to 4 ) and the experimental
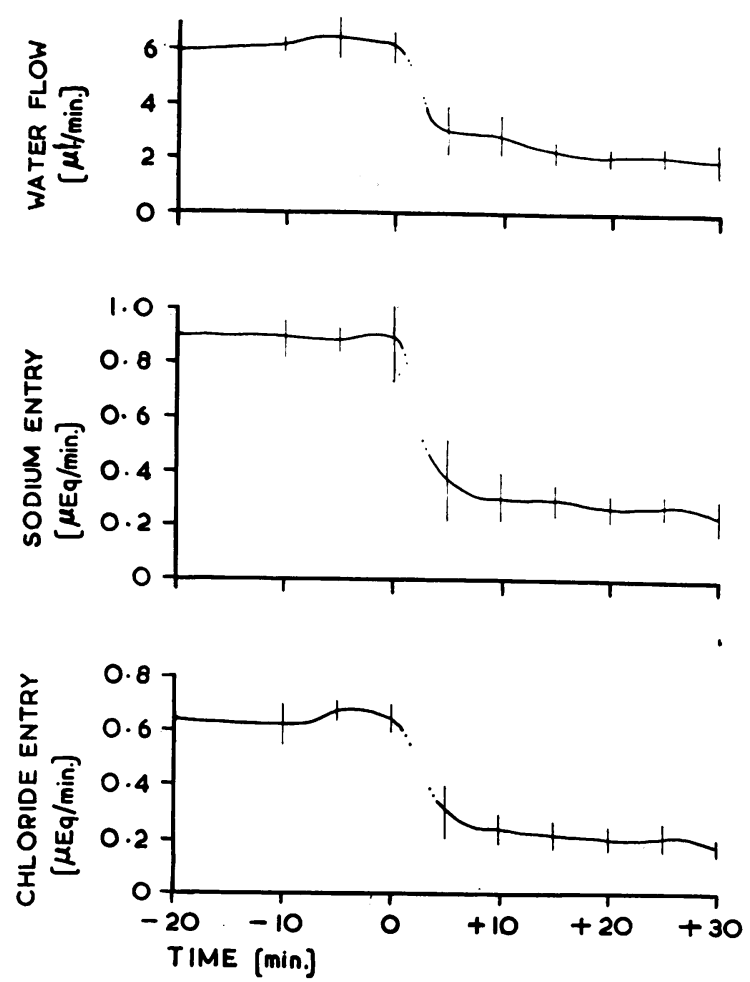

Fig. 2.- Rates of entry of water, sodium, and chloride into aqueous humour of animals given iodate at Time $=0$

Gap in continuous line for each substance indicates start of iodate infusion.

Vertical lines at each time-interval represent \pm twice the standard error of the mean. 
TABLE I

MEAN VALUES FOR INFLUX RATES OF WATER AND IONS AND FOR BLOODAQUEOUS P.D., BEFORE AND AFTER TREATMENT WITH IODATE, SPIROLACTONE, AND POLYPHLORETIN PHOSPHATE

\begin{tabular}{|c|c|c|c|c|c|}
\hline \multicolumn{3}{|c|}{ Substance } & \multirow{2}{*}{$\begin{array}{c}\begin{array}{c}\text { Before Infusion } \\
(-20 \text { to }-5 \text { min. })\end{array} \\
\begin{array}{c}6.06 \\
\pm 0.65\end{array}\end{array}$} & \multirow{2}{*}{$\begin{array}{c}\left.\begin{array}{c}\text { After Infusion } \\
(+10 \text { to }+30 \mathrm{~min} .\end{array}\right) \\
\begin{array}{c}1.59 \\
\pm 0.50\end{array}\end{array}$} & \multirow{2}{*}{$\begin{array}{l}\text { Difference } \\
-4 \cdot 47^{* *} \\
\pm 0 \cdot 40\end{array}$} \\
\hline \multirow{5}{*}{ Iodate } & \multirow{4}{*}{$\begin{array}{l}\text { Influx } \\
\text { Rate }\end{array}$} & $\begin{array}{c}\text { Water } \\
(\mu 1 . / \text { min. })\end{array}$ & & & \\
\hline & & $\underset{(\mu \mathrm{Eq} / \text { min. })}{\text { Sodium }}$ & $\begin{array}{l}0.893 \\
\pm 0.09\end{array}$ & $\begin{array}{l}\mathbf{0 . 2 2 4} \\
\pm \mathbf{0 . 0 9}\end{array}$ & $\begin{array}{l}-0.648^{* *} \\
\pm 0.09\end{array}$ \\
\hline & & \begin{tabular}{|c|} 
Chloride \\
$(\mu \mathrm{Eq} / \mathrm{min})$.
\end{tabular} & $\begin{array}{l}\mathbf{0 . 6 2 7} \\
\pm 0.07\end{array}$ & $\begin{array}{c}0 \cdot 198 \\
\pm 0.07\end{array}$ & $\begin{array}{l}-0.429 * * \\
\pm 0.07\end{array}$ \\
\hline & & $\underset{(\mu \mu \mathrm{Eq} / \mathrm{min} .)}{\text { Potassium }}$ & $\begin{array}{l}.30 .9 \\
\pm 1.7\end{array}$ & $\begin{array}{l}7 \cdot 95 \\
\pm 2 \cdot 1\end{array}$ & $\begin{array}{l}-23 \cdot 0^{* *} \\
\pm 2 \cdot 0\end{array}$ \\
\hline & \multicolumn{2}{|l|}{ P.D. } & $\begin{array}{r}5.91 \\
\pm 0.42\end{array}$ & $\begin{array}{r}0.50 \\
\pm 0.78\end{array}$ & $\begin{array}{l}-5 \cdot 41^{* *} \\
\pm 1 \cdot 1\end{array}$ \\
\hline \multirow{5}{*}{ Spirolactone } & \multirow{4}{*}{$\begin{array}{c}\text { Influx } \\
\text { Rate }\end{array}$} & $\begin{array}{l}\text { Water } \\
(\mu 1 / \text { min. })\end{array}$ & $\begin{array}{r}6.07 \\
\pm 0.49 \\
\end{array}$ & $\begin{array}{r}3 \cdot 38 \\
\pm 0 \cdot 42\end{array}$ & $\begin{array}{l}-2 \cdot 69^{* *} \\
\pm 0 \cdot 39\end{array}$ \\
\hline & & $\underset{(\mu \mathrm{Eq} / \mathrm{min} .)}{\text { Sodium }}$ & $\begin{array}{c}0.865 \\
\pm 0.06 \\
\end{array}$ & $\begin{array}{l}0.482 \\
\pm 0.05 \\
\end{array}$ & $\begin{array}{l}-0.353^{* *} \\
\pm 0.05 \\
\end{array}$ \\
\hline & & $\begin{array}{c}\text { Chloride } \\
(\mu \mathrm{Eq} / \mathrm{min} .)\end{array}$ & $\begin{array}{c}0.631 \\
\pm 0.06 \\
\end{array}$ & $\begin{array}{c}0.319 \\
\pm 0.09 \\
\end{array}$ & $\begin{array}{l}-0.312^{* *} \\
\pm 0.09\end{array}$ \\
\hline & & $\begin{array}{c}\text { Potassium } \\
(\mu \mu \mathrm{Eq} / \mathrm{min} .)\end{array}$ & $\begin{array}{r}29 \cdot 3 \\
\pm 1 \cdot 5\end{array}$ & $\begin{array}{r}14 \cdot 5 \\
\pm 2 \cdot 5\end{array}$ & $\begin{array}{c}-14 \cdot 8^{* * *} \\
\pm 2 \cdot 1\end{array}$ \\
\hline & \multicolumn{2}{|l|}{$\begin{array}{l}\text { P.D. } \\
\text { (mV) }\end{array}$} & $\begin{array}{l}6.21 \\
\pm 0.5\end{array}$ & $\begin{array}{l}1 \cdot 12 \\
\pm 0.8\end{array}$ & $\begin{array}{l}-5 \cdot 08^{* *} \\
\pm 1 \cdot 2\end{array}$ \\
\hline \multirow{5}{*}{$\begin{array}{c}\text { Polyphloretin } \\
\text { Phosphate }\end{array}$} & \multirow{4}{*}{$\begin{array}{l}\text { Influx } \\
\text { Rate }\end{array}$} & $\begin{array}{c}\text { Water } \\
(\mu 1 . / \mathrm{min} .)\end{array}$ & $\begin{array}{r}5.63 \\
\pm 0.21\end{array}$ & $\begin{array}{r}3.93 \\
\pm 0.36 \\
\end{array}$ & $\begin{array}{l}-1 \cdot 70^{*} \\
\pm 0.57\end{array}$ \\
\hline & & $\begin{array}{c}\text { Sodium } \\
(\mu \mathrm{Eq} / \mathrm{min} .)\end{array}$ & $\begin{array}{c}\mathbf{0 . 8 0 3} \\
\pm 0.05 \\
\end{array}$ & $\begin{array}{c}\mathbf{0 . 5 5 4} \\
\pm \mathbf{0 . 0 5} \\
\end{array}$ & $\begin{array}{l}-0.250^{*} \\
\pm 0.08\end{array}$ \\
\hline & & $\begin{array}{c}\text { Chloride } \\
(\mu \mathrm{Eq} / \mathrm{min} .)\end{array}$ & $\begin{array}{l}0.585 \\
\pm 0.06\end{array}$ & $\begin{array}{c}0.409 \\
\pm 0.07\end{array}$ & $\begin{array}{l}-0 \cdot 185^{*} \\
\pm 0.07\end{array}$ \\
\hline & & $\begin{array}{c}\text { Potassium } \\
(\mu \mu \mathrm{Eq} / \mathrm{min} .)\end{array}$ & $\begin{array}{r}28.5 \\
\pm 1.8\end{array}$ & $\begin{array}{r}20 \cdot 2 \\
\pm 2 \cdot 4\end{array}$ & $\begin{array}{l}-8 \cdot 8^{*} \\
\pm 3 \cdot 2\end{array}$ \\
\hline & \multicolumn{2}{|l|}{ P.D. } & $\begin{aligned} & 6 \cdot 11 \\
\pm & 0 \cdot 6\end{aligned}$ & $\begin{aligned} & 6 \cdot 27 \\
\pm & 0 \cdot 7\end{aligned}$ & $\begin{array}{l} \pm 0 \cdot 16 \\
\pm 0.9\end{array}$ \\
\hline
\end{tabular}

Values differing significantly from zero in the right hand column (differences) are indicated by asterisks; the range $0.05>P>0.01$ is shown by $*$, and the range $0.01>P$ by $* *$.

mean from values lying between 10 and $30 \mathrm{~min}$. after the start of the infusion (i.e. from +10 to $+30 \mathrm{~min}$. in Figs 2 to 4). In all cases means were derived from results on at least ten different animals. 

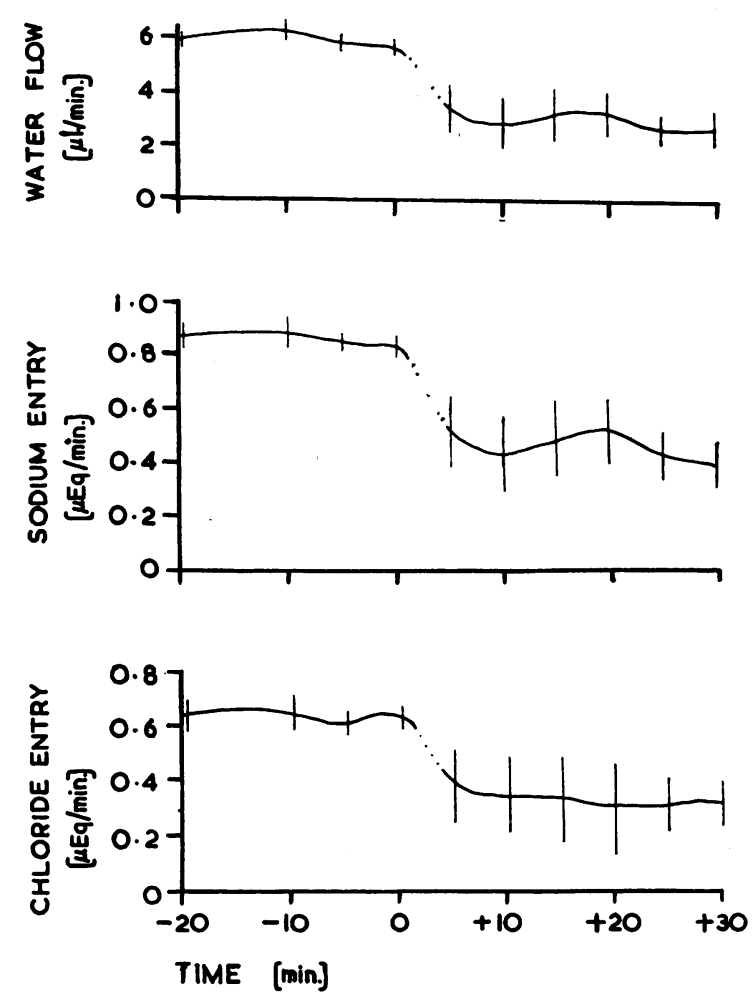

Fig. 3.-Rates of entry of water, sodium, and chloride into aqueous humour of animals given spirolactone at Time $=0$.

Gap in continuous line for each substance indicates start of spirolactone administration.

Vertical lines at each time-interval represent \pm twice the standard error of the mean.

Table II shows the values for influx, aqueous concentration, bloodaqueous P.D., and changes in tonometer reading which were observed in the long-term iodate experiments. The course of the intra-ocular pressure changes is also shown in Fig. 5 (opposite).

TABLE II

RATES OF INFLUX, AQUEOUS CONCENTRATION, CHANGES IN BLOOD-AQUEOUS P.D. AND TONOMETER READINGS IN CONTROL RABBITS AND IN RABBITS 12 DAYS AFTER I/V ADMINISTRATION OF SODIUM IODATE

\begin{tabular}{|c|c|c|c|c|c|c|c|c|c|}
\hline \multirow{2}{*}{ Series } & \multicolumn{4}{|c|}{ Influx Rate } & \multicolumn{3}{|c|}{ Aqueous Concentration $\left(c_{a}\right)$} & \multirow{2}{*}{$\begin{array}{c}\text { Change } \\
\text { in } \\
\text { P.D. } \\
\text { (mV) }\end{array}$} & \multirow{2}{*}{$\begin{array}{l}\text { Change in } \\
\text { Schiötz } \\
\text { Reading } \\
\text { (12th day } \\
\text { minus Con- } \\
\text { trol period) }\end{array}$} \\
\hline & $\begin{array}{c}\text { Water } \\
(\mu 1 . / \mathrm{min} .)\end{array}$ & $\underset{(\mu \mathrm{Eq} / \mathrm{min} .)}{\mathrm{Na}}$ & $\underset{(\mu \mathrm{Eq} / \mathrm{min} .)}{\mathrm{Cl}}$ & $\mid \underset{(\mu \mu \mathrm{Eq} / \mathrm{min} .)}{\mathbf{K}}$ & $\underset{(\mu \mathrm{Eq} / \mathrm{ml} .)}{\mathrm{Na}}$ & $\underset{(\mu \mathrm{Eq} / \mathrm{ml} .)}{\mathrm{Cl}}$ & $\underset{(\mu \mathrm{Eq} / \mathrm{ml} .)}{\mathbf{K}}$ & & \\
\hline $\begin{array}{l}\text { Control } \\
12 \text { days) }\end{array}$ & $\begin{array}{r}5.30 \\
\pm 0.23\end{array}$ & $\begin{aligned} & 0.766 \\
\pm & 0.09\end{aligned}$ & $\begin{aligned} & 0.582 \\
\pm & 0.10\end{aligned}$ & $\begin{array}{r}25.2 \\
\pm 2.7\end{array}$ & $\begin{array}{r}142.5 \\
\pm 2 \cdot 3\end{array}$ & $\begin{array}{r}110.3 \\
\pm 1.4\end{array}$ & $\begin{array}{r}4.75 \\
\pm 0.19\end{array}$ & $\begin{array}{r}+5.53 \\
\pm 0.40\end{array}$ & $\begin{array}{l}+0.11 \\
\pm 0.59\end{array}$ \\
\hline Iodate & $\begin{array}{r}2.49 \\
\pm 0.26 * * \\
\end{array}$ & $\begin{array}{r}0.337 \\
\pm 0 \cdot 10^{* *}\end{array}$ & $\begin{array}{r}0.283 \\
\pm 0.09^{* *}\end{array}$ & $\begin{array}{c}10 \cdot 9 \\
\pm 3 \cdot 2^{* *}\end{array}$ & $\begin{array}{r}139 \cdot 5 \\
\pm 2 \cdot 3\end{array}$ & $\begin{array}{r}108.9 \\
\pm 2.4\end{array}$ & $\begin{array}{r}4.35 \\
\pm 0.35\end{array}$ & $\begin{array}{c}+0.04 \\
\pm 1.47^{* *}\end{array}$ & $\begin{array}{l}+2.50^{* *} \\
\pm 0.13\end{array}$ \\
\hline
\end{tabular}

The significance of changes is indicated by asterisks: the range $0.05>P>0.01$ is shown by ${ }^{*}$, and the range

Values differing significantly from zero in the right hand column (differences) are indicated by asterisks. 

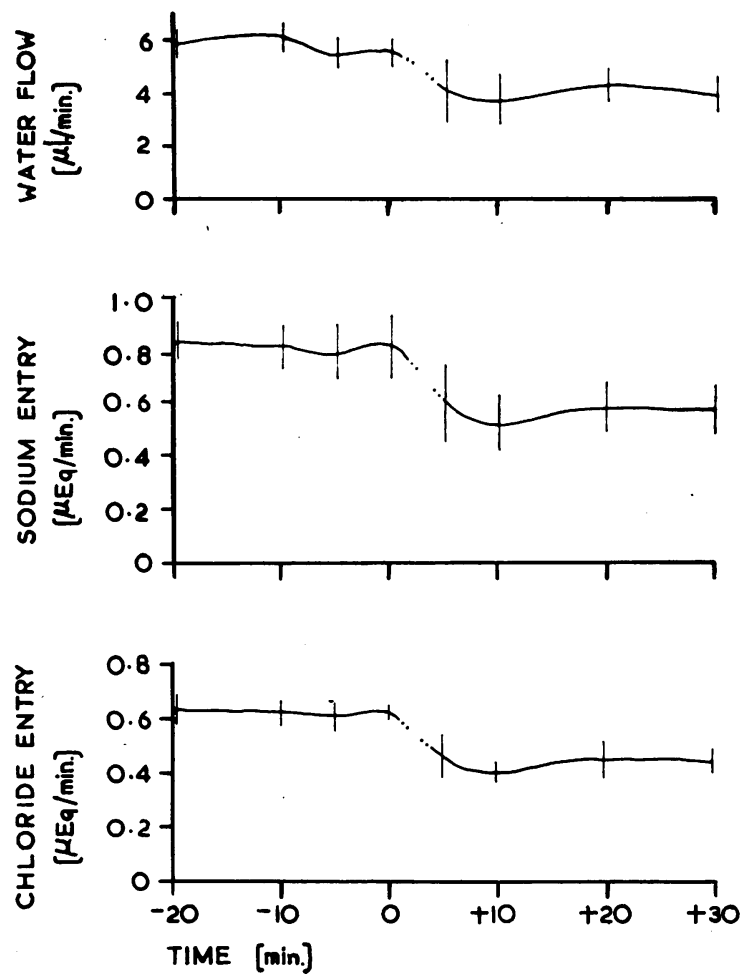

FIG. 4. - Rates of entry of water, sodium, and chloride into aqueous humour of animals given PPP at Time $=0$.

Gap in continuous line for each substance indicates start of PPP infusion.

Vertical lines at each time-interval represent \pm twice the standard error of the mean.

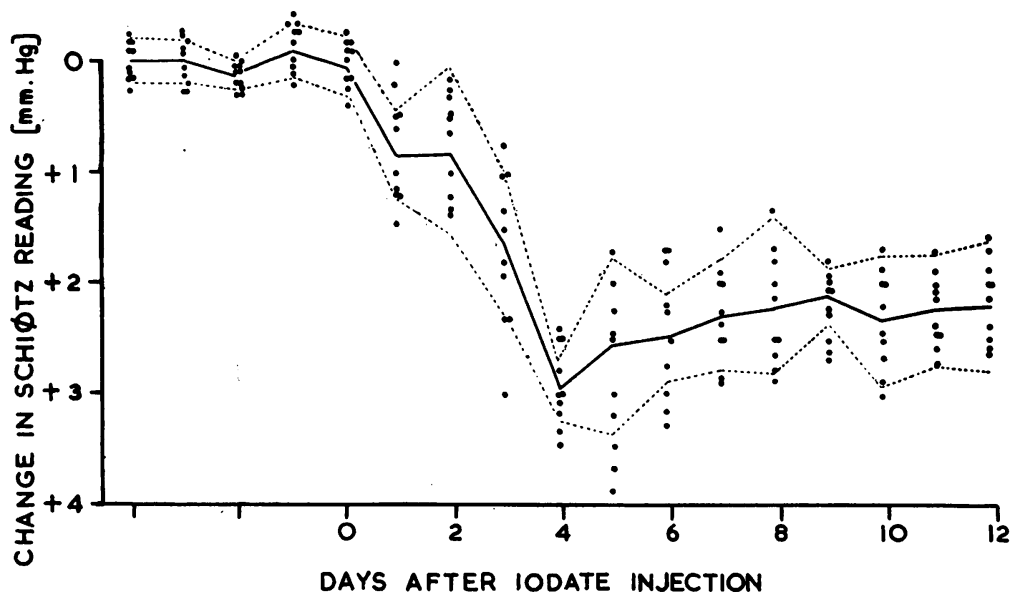

FIG. 5.-Change in intra-ocular pressure (represented by change in Schiötz tonometer reading) after intravenous administration of 2 per cent. sodium iodate at Day zero. Points represent actual changes in Schiötz reading.

Broken lines represent $t$ twice the standard error of the mean for each day.

Calibration showed that a change in Schiötz reading of +3.0 divisions corresponded to a fall in intra-ocular pressure of about $5.5 \mathrm{~mm}$. $\mathrm{Hg}$. 
The Schiötz calibration results showed that, in most cases, a change in tonometer reading of +3.0 divisions corresponded to a fall in intra-ocular pressure of about $5.5 \mathrm{~mm}$. $\mathrm{Hg}$. The values for plasma and aqueous concentration and for the aqueous concentration ratios, $r_{a p}$, for the spirolactone experiments are shown in Table III.

TABLE III

MEAN VALUES FOR AQUEOUS AND PLASMA WATER CONCENTRATIONS OF SODIUM CHLORIDE AND POTASSIUM AFTER TREATMENT WITH SPIROLACTONE

\begin{tabular}{|c|c|c|c|c|}
\hline \multicolumn{2}{|l|}{ Substance } & $\begin{array}{l}\text { Before Infusion } \\
(-20 \text { to }-5 \mathrm{~min} .)\end{array}$ & $\begin{array}{c}\text { After Infusion } \\
(+10 \text { to }+30 \mathrm{~min} .)\end{array}$ & Difference \\
\hline Aqueous Concentration $\left(c_{a}\right)$ & $\begin{array}{c}\mathrm{Na} \\
\mathrm{Cl} \\
\mathrm{K}\end{array}$ & $\begin{array}{c}151 \cdot 7 \\
\pm 2 \cdot 6 \\
102 \cdot 6 \\
\pm 2 \cdot 6 \\
5.02 \\
\pm 0 \cdot 25\end{array}$ & $\begin{array}{c}153.2 \\
\pm 2.2 \\
103.7 \\
\pm 3.0 \\
5.06 \\
\pm 0.21\end{array}$ & $\begin{array}{l} \pm 0.72 \\
\pm 0.95 \\
+1.13 \\
\pm 1.9 \\
+0.01 \\
\pm 0.20\end{array}$ \\
\hline Plasma Water Concentration $\left(c_{p}\right)$ & $\begin{array}{l}\mathrm{Na} \\
\mathrm{Cl} \\
\mathrm{K}\end{array}$ & $\begin{array}{c}158.0 \\
\pm 1 \cdot 2 \\
103.0 \\
\pm 1 \cdot 3 \\
5.14 \\
\pm 0.30\end{array}$ & $\begin{array}{c}158 \cdot 3 \\
\pm 1 \cdot 2 \\
104 \cdot 0 \\
\pm 1 \cdot 2 \\
5 \cdot 20 \\
\pm 0.20\end{array}$ & $\begin{array}{l}+0.31 \\
\pm 1.1 \\
\pm 0.89 \\
\pm 1.7 \\
+0.02 \\
\pm 0.10\end{array}$ \\
\hline Aqueous/Plasma Ratio ( $\left.r_{a p}\right)$ & $\begin{array}{l}\mathrm{Na} \\
\mathrm{Cl} \\
\mathrm{K}\end{array}$ & $\begin{array}{c}0.961 \\
\pm 0.23 \\
0.998 \\
\pm 0.02 \\
0.978 \\
\pm 0.02\end{array}$ & $\begin{array}{c}0.967 \\
\pm 0.02 \\
0.995 \\
\pm 0.01 \\
0.974 \\
\pm 0.02\end{array}$ & $\begin{array}{l}+0.008 \\
\pm 0.06 \\
-0.007 \\
\pm 0.03 \\
-0.025 \\
\pm 0.017\end{array}$ \\
\hline \multicolumn{2}{|l|}{ Sodium/Potassium Ratio of Aqueous } & $\begin{array}{c}30.59 \\
\pm 3.2\end{array}$ & $\begin{array}{c}30 \cdot 12 \\
\pm 3.5\end{array}$ & $\begin{array}{l}-2 \cdot 40 \\
\pm 2 \cdot 1\end{array}$ \\
\hline
\end{tabular}

All the drugs reduced the sodium, chloride, and water influx to the aqueous; the effect was greatest with iodate and least with PPP (Figs 2, 3, 4; Table I), although the concentrations of sodium, chloride, and potassium in the aqueous were not significantly altered even with spirolactone (Table III).

Both spirolactone and iodate reduced the blood-aqueous P.D. (Figs 6 and 7), but PPP caused no significant change.

The long-term treatment with iodate resulted in severe damage to the pigment epithelium of the retina, although there was no unequivocal evidence that the pigment-cell layer of the ciliary body was affected to the same extent. The appearance of the retina was similar to that described by Kalt (1937) and somewhat resembled the findings of Ashton (1957) in poisoning with 1:5-di ( $p$-aminophenoxy)pentane.

\section{Discussion}

It appears reasonable to distinguish between the actions of iodate and spirolactone and that of PPP on the grounds that the latter substance does 
not diminish the blood-aqueous P.D. and that it does not reduce the sodium and water inflow to the same extent. The reduction in inflow caused by PPP (approximately 30 per cent. of the control value) is also much less than that caused by 2,4-dinitrophenol, fluoracetamide, or strophanthin-G (Cole, 1960b, 1961a), and there seems to be no evidence that PPP acts as an inhibitor of cell metabolism. Earlier experiments have shown that the movement of water and electrolytes from blood to aqueous humour, even in the presence of an inhibitor such as dinitrophenol, continues at a reduced rate possibly by ultrafiltration. This non-inhibited fraction of the influx constitutes some 30 per cent. of the total (Cole, 1960a, b) and the present finding of a decrease in the influx rate by some 30 per cent. in PPP-treated animals is consistent with the view that this substance acts by decreasing the permeability of the blood-aqueous barrier. In the absence of any change in the blood-aqueous P.D. which would result from inhibition of active ion transport, reduction of permeability offers an adequate explanation of the action of PPP.

The action of iodate appears to be rather more complicated; the series of acute experiments shows that it is rapid in onset (Figs 2 and 6) and decreases the inflow rate by some 70 per cent. or more within $30 \mathrm{~min}$. In the longterm experiments, a single intravenous injection of iodate caused the intraocular pressure to fall to a minimum value within 4 days (Fig. 5) and to remain subnormal for a further 8 days. The changes in blood-aqueous P.D. are similar to the changes in inflow rate. Histologically, the iodate intoxication affected the pigment epithelium of the retina rather than that of the ciliary body and, if one were to consider only the changes of potential, it might be supposed that the findings could be accounted for by a fall in the retinal standing potential caused by the action of iodate ( $c f$. Noell, 1953, 1954). However, to explain the observed changes in intra-ocular pressure and aqueous formation in terms of retinal injury alone, it would be necessary to suppose either that the normal retina produces a considerable fraction (more than 50 per cent.) of the aqueous, which would need to pass through the vitreous in order to reach the anterior segment of the eye, or alternatively, that iodate by diminishing the resistance of the retina and hence of the blood-vitreous

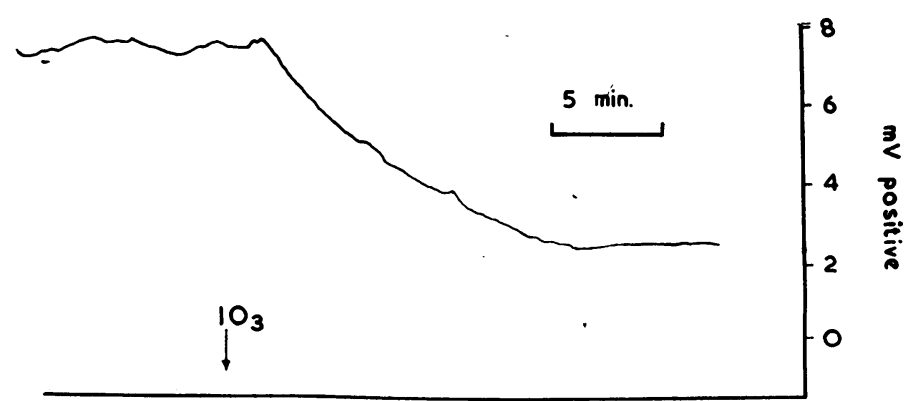

FIG. 6. - Recording of blood-aqueous P.D. during administration of iodate $\left(\mathrm{I}_{3}\right), 0.01 \mathrm{mM} / \mathrm{min}$., via the lingual artery. 
barrier, allows some of the aqueous formed in the posterior chamber to pass through the vitreous and the blood-vitreous barrier without entering the anterior chamber. Neither hypothesis seems at all probable, for both require a nett flow through the vitreous of some $0.65 \mu \mathrm{Eq} \mathrm{Na}{ }^{\circ}$ and $4.5 \mu l$. water per min., these values being the mean changes in aqueous flow observed after the acute administration of iodate (Table I), and this is not supported by Maurice's studies on vitreous dynamics (Maurice, 1957, 1959) nor by the high resistance to bulk flow which would be offered by the hyaluronic acid in the vitreous body (cf. Ogston and Sherman, 1961). Furthermore, the results reported by de Rosa and de Vincentiis (1953) indicate an accumulation of end-products of nitrogen metabolism in the vitreous after iodate administration, and this could hardly occur if there was a considerable bulk flow of water through the vitreous and the blood-vitreous barrier.

The most likely explanation for the action of iodate seems to be that it reduces aqueous inflow by damaging the secretory system of the ciliary body, and this view is supported by the fact that chronic iodate intoxication reduces the bicarbonate and ascorbate concentrations of the aqueous to approximate equality with the plasma (Gemolotto, 1954; Ambrosio, 1956) as well as from the pathological changes of the ciliary body reported by Umadzume (1929). In the long-term experiments it is possible that iodate caused some liver damage, as described by Kalt (1937), but it cannot well be maintained that the ocular effects are secondary on account of the rapid onset of the electrical and inflow changes in the acute experiments. There is evidence for some degree of recovery from iodate administration so far as the bicarbonate concentration of the aqueous is concerned (Ambrosio, 1956), and this may account for the difference between the inflow rates in the acutely and chronically-treated animals in the present experiments.

The spirolactone used in these experiments was "Aldactone" (G. D. Searle and Co., High Wycombe, Bucks.), the 19-nor analogue of 3-(3-oxo-17 $\beta$ hydroxy-4-androsten-17 $\alpha$-yl)-propionic acid $\gamma$-lactone, which acts as a peripheral antagonist of aldosterone (Kagawa, Sturtevant, and van Arman, 1959), notably in decreasing renal tubular reabsorption of sodium (Liddle, 1958; Vander, Wilde, and Malvin, 1960). In the present experiments the decreased influx of water and sodium is associated with a fall in bloodaqueous P.D., but in many cases this fall was preceded by a temporary increase (Fig. 7, opposite). This suggests that the inhibition occurs in two stages, but the details of the process remain uncertain. One possibility is that the spirolactone acts first on the ciliary pigment epithelium decreasing the blood-intracellular P.D. and secondly on the unpigmented layer; it has been suggested previously that elimination or reduction of the negative potential from stroma to pigment cell could, on the basis of Berggren's findings (Berggren, 1960), result in an overall increase in the blood-aqueous P.D. (Cole, 1961a). The biphasic change would then result from the spirolactone's affecting first the pigment layer and later the unpigmented cells. Another explana- 


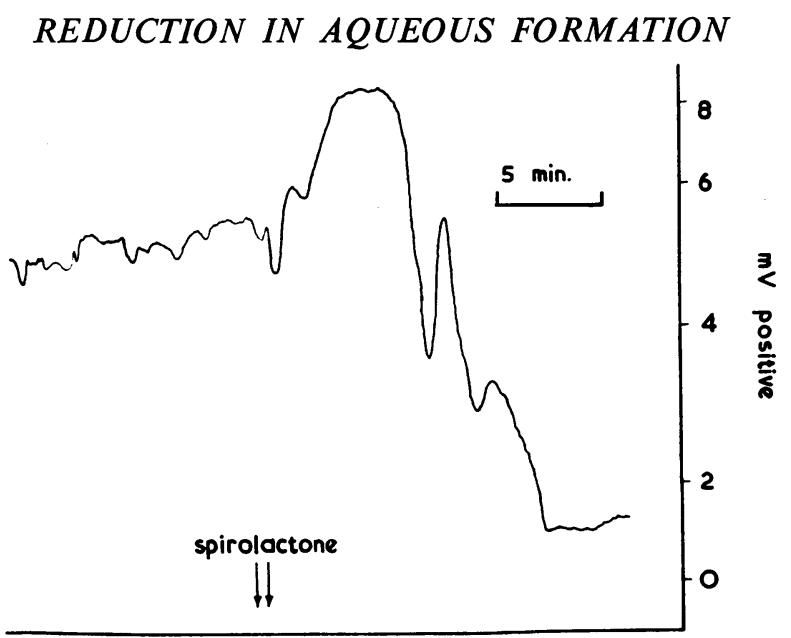

Fig. 7.- Recording of blood-aqueous P.D. during administration of $5 \mathrm{mg}$. spirolactone via the carotid artery.

tion assumes the existence of a $\mathrm{Na} / \mathrm{K}$ pump, extruding $\mathrm{Na}$ from the epithelial cells into the aqueous in exchange for $\mathrm{K}^{\circ}$ (Cole, 1961c). Should the sites on the pump for uptake of $\mathrm{K}^{\circ}$ be the first to be inactivated by the spirolactone whilst some $\mathrm{Na}$ extrusion continues, then the P.D. will rise until the $\mathrm{Na}^{\cdot}$ sites are also inactivated, when the blood-aqueous P.D. will fall towards zero. Not enough is known of the intracellular action of spirolactone to decide between these possibilities.

The reduction in aqueous inflow caused by spirolactone $(47 \cdot 2$ per cent. after $20 \mathrm{~min}$.) is less than that due to iodate $(67.9$ per cent.) in the present experiments or to fluoracetamide $(62.4$ per cent. in earlier experiments: Cole, 1960b). However, there is evidence that cellular systems for $\mathrm{Na}^{\circ}$ transport continue to operate in the effective absence of adrenal cortical steroids, although at a diminished rate or against a diminished concentration gradient. Thus Vander, Wilde, and Malvin (1960) have shown that distal tubular $\mathrm{Na}^{\circ}$ reabsorption against a concentration gradient continues in adrenalectomized dogs, or in dogs treated with spirolactone, although the process is less effective than in the presence of aldosterone. The action of iodate on the retina might be a further reason for the more severe reduction in aqueous formation which follows its administration as compared with that of spirolactone, for it has already been indicated that the retinal standing potential should contribute to the blood-aqueous P.D. and ipso facto should be related to the movement of ions between the plasma and the intra-ocular fluids (Cole, 1961b).

In the renal tubule it appears that spirolactone decreases $\mathrm{Na}^{\circ}$ reabsorption from the lumen in exchange for $\mathrm{K}^{\circ}$ (Liddle, 1958; Kagawa and others, 1959), but in the aqueous there was no evidence for any change of $c_{a}$ or $r_{a p}$ for either sodium or potassium, nor was the $[\mathrm{Na}] /[\mathrm{K}]$ ratio in aqueous significantly altered (Table III). This is probably due to the fact that the concentration 
gradient between plasma and aqueous is much smaller than that between tubular urine and blood. In addition, diffusion of potassium into and out of regions surrounding the aqueous (plasma, vitreous, lens) would render it difficult to detect small changes in the concentration of this ion. It is very unlikely that these results are due to changes in outflow, for the drainage channels were obstructed during the measurement of inflow, and, in any case, it is unlikely that spirolactone would enter the aqueous so rapidly that its concentration in the anterior chamber could explain the rapid changes in flow rate and blood-aqueous P.D. Neither is it likely that systemic effects of spirolactone would contribute to these results, as the experiments were terminated $30 \mathrm{~min}$. after starting the infusion and, in any case, the plasma electrolyte concentrations were not significantly changed (Table III).

If the process of $\mathrm{Na}^{\circ}$ transport in the ciliary body is at all similar to that in the kidney, spirolactone must be assumed to act as an aldosterone antagonist and the present findings would thus imply that the normal rate of aqueous formation is dependent, at least in part, to the presence of endogenous aldosterone. This conclusion receives some support from Linnér's findings in man (1959a, b). Kinsey, Camacho, Cavanaugh, Constant, and McGinty (1955) have shown that aldosterone may improve the responsiveness of the intra-ocular pressure to Diamox, but Becker and Constant (1955) and Becker (1956) considered that the steroid acted upon the outflow system. More recently Linnér $(1959 \mathrm{a}, \mathrm{b})$ has shown that prednisolone increases intra-ocular pressure and inflow independently of the outflow, and the present results demonstrate that an aldosterone (i.e. a mineralocorticoid) antagonist diminishes the influx rate.

\section{Summary}

(1) In the present experiments, direct measurements of the influx rates of water and electrolytes from plasma to aqueous humour were made, and it was found that the rate of formation of the aqueous was reduced by the administration of polyphloretin phosphate, spirolactone, and iodate, in increasing order of effectiveness.

(2) Polyphloretin phosphate reduced the influx of the constituents studied by about 30 per cent. without altering the blood-aqueous potential difference; it probably acts by reducing the permeability of the barrier, rather than by inhibiting an active transport process.

(3) Spirolactone reduced the influx by about 47 per cent. and affected also the blood-aqueous P.D. The fact that formation is reduced by this peripheral aldosterone antagonist leads to the following implications:

(a) Sodium transport is involved in the normal process of aqueous formation;

(b) The normal aqueous formation is partly dependent upon endogenous aldosterone. 
(4) Iodate, in acute experiments, reduced the influx by about 68 per cent. and abolished the blood-aqueous P.D. It would appear to act upon the ciliary body, since these findings are not explicable in terms of the known effects of iodate on the retina, although reduction of retinal potential may contribute to the diminished influx.

(5) In long-term (12-day) experiments, iodate caused a persistent fall in intra-ocular pressure, influx, and blood-aqueous P.D.

The author wishes to thank Dr. K. Tansley for the preparation of histological material and advice concerning its interpretation. Thanks are also due to Dr. G. R. Venning, of G. D. Searle and Co., High Wycombe, Bucks., for a gift of "Aldactone", and to Dr. B. Hogberg, of A. G. Leo, Halsingborg, Sweden, for a gift of polyphloretin phosphate.

\section{REFERENCES}

Ambrosio, A. (1956). G. ital. Oftal., 9, 636.

Astron, N. (1957). J. Path. Bact., 74, 103.

BECKER, B. (1956). In "Glaucoma: Transactions of the First Conference, 1955", ed. F. W. Newell, pp. 184-187, Josiah Macy, Jr., Foundation, New York. and Constant, M. A. (1955). A.M.A. Arch. Ophthal., 54, 321.

BERGGREN, L. (1960). Acta physiol. scand., 48, 461.

Bertolacini, R. J. and Barney, J. E., II (1958). Analyt. Chem., 30, 202.

Cella, J. A., and Kagawa, C. M. (1957). J. Amer. chem. Soc., 79, 4808.

Cole, D. F. (1959). Brit. J. Ophthal., 43, 268.

(1960a). Ibid., 44, 225-245.

(1960b). Ibid., 44, 739-750.

(1961a). Ibid., 45, 202-217.

(1961b). Ibid., 45, 482.

(1961c). Ibid., 45, 641 .

DE Rosa, L., and DE VINCENTIIS, M. (1953). Rass. ital. Ottal., 22, 481.

Diczfalusy, E., Fernö, O., Fex, H., Högberg, B., Linderot, T., and Rosenberg, T. (1953). Acta chem. scand., 7, 913 .

Fries, B. (1956). Acta chir. scand., Suppl. 217. (1960). Ibid., 119, 1 .

Gemolotto, G. (1954). G. ital. Oftal., 7, 75.

Kagawa, C. M., Cella, J. A., and van Arman, C. G. (1957). Science, 126, 1015.

Sturtevant, F. M., and van Arman, C. G., (1959). J. Pharmacol., 126, 123-130.

Kalt, M. E. (1937). Bull. Soc. ophtal. Paris, p. 304.

Kinsey, V. E., Camacho, E., Cavanaugh, G. A., Constant, M., and McGinty, D. A. (1955). A.M.A. Arch. Ophthal., 53, 680.

LiDDLE, G. W. (1957). Science, 126, 1016.

(1958). Arch. intern. Med., 102, 998.

LINNÉr, E. (1959a). Trans. ophthal. Soc. U.K., 79, 27. (1959b). Docum. ophthal., 13, 210.

MAUrice, D. M. (1957). J. Physiol. (Lond.), 137, 110. (1959). Amer. J. Ophthal., 47, 361.

Noell, W. K. (1953). U.S.A.F. School of Aviation Medicine, Project No. 21-1201-0n04, Report No. 1.

(1954). Amer. J. Ophthal., 38, No. 1, Pt 2, p. 78.

Ogston, A. G., and Sherman, T. F. (1961). J. Physiol. (Lond.), $156,67$.

SORSBY, A. (1941). Brit. J. Ophthal., 25, 58.

UMADZUME, K. (1929). Abstracted in Zbl. Ophthal. (1930). 22, 836.

VANDER, A. J., Wilde, W. S., and Malvin, R. S. (1960). Proc. Soc. exp. Biol. (N. Y.), 103, 525

VITo, P. (1935). Boll. Oculist., 14, 945. 